\title{
15. STABLE ISOTOPIC RESULTS ON UPPER MIOCENE AND LOWER PLIOCENE FORAMINIFERS FROM HOLE 552A ${ }^{1}$
}

\author{
Lloyd D. Keigwin, Jr., Woods Hole Oceanographic Institution ${ }^{2}$
}

\section{INTRODUCTION}

This chapter summarizes preliminary stable isotopic results on benthic and planktonic foraminifers from the upper Miocene and lower Pliocene sections of DSDP Hole 552A. Shackleton and Hall (this volume) has provided considerable isotopic detail from a section stratigraphically higher in Hole 552A (middle Pliocene-Pleistocene).

Study of this site was undertaken as part of a general study of Neogene stable isotopic change in open ocean North Atlantic sites. Blanc et al. (1980) published results from the only previously drilled North Atlantic location, DSDP Site 116. Other studies concentrated on the isotopic records from marginal seas (Gulf of Mexico, Brunner and Keigwin, 1981; Caribbean, Keigwin, 1982; Mediterranean Sea, Keigwin and Thunnell, 1979) or from nearshore locations (continental margin off West Africa, Shackleton and Cita, 1979). Results from Blanc et al. (1980) reveal general trends in Neogene isotopic history of the North Atlantic, but since Site 116 was only spot-cored, detailed study of specific isotopic features is difficult.

Within upper Miocene and lower Pliocene sections of other DSDP sections, previous studies have revealed changes in $\delta^{18} \mathrm{O}$ and $\delta^{13} \mathrm{C}$ of foraminifers which may have resulted from changing oceanographic or climatic conditions. For example, Kennett et al. (1979) noted small $\delta^{18} \mathrm{O}$ changes in Pliocene sediments of $\sim 3.5 \mathrm{~m}$.y. age and in latest Miocene sediments at southwest Pacific DSDP Site 284. Several increases and decreases of $\sim 0.5 \%$ in $\delta^{18} \mathrm{O}$ were found in upper Miocene sediments at eastern equatorial Pacific DSDP Site 158 (Keigwin, 1979), and an enrichment in ${ }^{18} \mathrm{O}$ of planktonic foraminifers at DSDP 502 was thought to be the result of an increase in Caribbean salinity in the early Pliocene (Keigwin, 1982). A decrease in $\delta^{13} \mathrm{C}$ of latest Miocene foraminifers has been found throughout the Indo-Pacific region (for example, Keigwin, 1979; Bender and Keigwin, 1979; Vincent et al., 1980) but has not yet been clearly identified in open ocean North Atlantic sediments.

It is important to know if these late Miocene and early Pliocene isotopic events are local, basinwide, or oceanwide in extent. Hole 552A was sampled at coarse intervals (on the order of meters, equal to time-spacing of hundreds of thousands of years) to determine the gen-

\footnotetext{
${ }^{1}$ Roberts, D. G., Schnitker, D., et al., Init. Repts. DSDP, 81: Washington (U.S. Govt. Printing Office).

2 Address: Woods Hole Oceanographic Institution, Woods Hole, MA 02543.
}

eral nature of oxygen and carbon isotopic variation in foraminifers for comparison with other locations. The results of this preliminary study are being used as a framework for a detailed study now in progress.

\section{METHODS}

Samples of about $10 \mathrm{~cm}^{3}$ were taken from intervals of $\sim 2 \mathrm{~cm}$ thickness, disaggregated in hot sodium metaphosphate, and washed over a $63 \mu \mathrm{m}$ sieve. A portion of the $<63 \mu \mathrm{m}$ fraction was saved for future use, including study of diatoms (Baldauf, this volume). The coarse fraction was dried and the benthic foraminiferal genus Cibicidoides was picked from the $>150 \mu \mathrm{m}$ fraction. Globigerina bulloides was picked from the same fraction and later sieved again at $300 \mu \mathrm{m}$ for isotopic analysis within a discrete size fraction.

Stable isotopic analysis followed standard procedures (Keigwin, 1979) with the following modifications: all samples were cleaned ultrasonically in methanol, benthic foraminifers were crushed with a glass rod in methanol in the sample-carrying boats prior to roasting in $v a$ $\mathrm{cuo}$ at $370^{\circ} \mathrm{C}$ for one hour, and condensibles were frozen in liquid nitrogen as the calcite dissolved. Results were converted to PDB via the secondary standard NBS-20.

\section{RESULTS AND DISCUSSION}

Results of stable isotopic analyses at this site are presented in Table 1 and Figure 1. Oxygen isotopic results of benthic and planktonic foraminifers each fall within about $1 \%$ limits, consistent with results at other sites which show the late Miocene and early Pliocene $(\sim 10$ to 3 m.y.) to be times of zero net growth in continental ice. The apparent covariance of $\delta^{18} \mathrm{O}$ between benthics and planktonics is suggestive of a seawater compositional effect resulting from growth and decay of continental ice, but synchronous temperature changes between the near surface and deep sea cannot be ruled out. It is not yet possible to correlate variability in $\delta^{18} \mathrm{O}$ between different upper Miocene and lower Pliocene sections, because changes are small compared to those found in middle Miocene and upper Pliocene to Quaternary sections. Of possible significance is $\delta^{18} \mathrm{O}$ evidence of two upper Miocene coolings-one at $\sim 120 \mathrm{~m}$ and one at the Miocene/Pliocene boundary (Fig. 1).

Carbon isotopic composition of benthic and planktonic foraminifers also covaries (Fig. 1). A general trend of decreasing $\delta^{13} \mathrm{C}$ exists, as is seen at other sites (see for example: Keigwin, 1979; Shackleton and Cita, 1979; Shackleton and Kennett, 1975; Woodruff, et al., 1981), but it is not yet clear how the record at Hole 552A correlates with these others. For example, the negative carbon isotopic change ("carbon shift") dated at $\sim 6 \mathrm{~m}$.y. at other locations (Loutit and Kennett, 1979; Keigwin and Shackleton, 1980) is not a prominent feature at Hole $552 \mathrm{~A}$. In fact, there appear to be three $\delta^{13} \mathrm{C}$ decreases at this site, at $\sim 140 \mathrm{~m}, 120-130 \mathrm{~m}$ (planktonic foraminifers only), and $\sim 90 \mathrm{~m}$. The position of the 
Table 1. Stable isotopic results, Hole 552A foraminifers (PDB, $\% 0$ ).

\begin{tabular}{|c|c|c|c|c|c|c|c|}
\hline \multirow[b]{2}{*}{ Sample } & \multirow{2}{*}{$\begin{array}{l}\text { Depth } \\
\text { (m) }\end{array}$} & \multicolumn{2}{|c|}{ G. bulloides } & \multicolumn{2}{|c|}{$\begin{array}{l}\text { C. wueller- } \\
\text { storfi }\end{array}$} & \multicolumn{2}{|c|}{ C. kullenbergi } \\
\hline & & $\delta^{18} \mathrm{O}$ & $\delta^{13} \mathrm{C}$ & ${ }_{\delta}^{18} \mathrm{O}$ & ${ }^{13} \mathrm{C}$ & $\delta^{18} \mathrm{O}$ & $\delta^{13} \mathrm{C}$ \\
\hline $14-1,102$ & 63.02 & 1.26 & -0.68 & 2.18 & 0.65 & & \\
\hline $14-2,101$ & 64.51 & 1.39 & -0.38 & 2.63 & 0.87 & 2.87 & -0.01 \\
\hline $14-3,102$ & 66.02 & 1.19 & 0.16 & 2.42 & 0.94 & & \\
\hline $15-1,098$ & 67.98 & 1.04 & -0.23 & 1.91 & 0.69 & & \\
\hline $15-2,102$ & 69.52 & 1.45 & -0.11 & 2.31 & 0.89 & & \\
\hline $15-3,105$ & 71.05 & 1.04 & -0.48 & 2.35 & 0.98 & & \\
\hline $16-1,102$ & 73.02 & 1.07 & -0.21 & 2.20 & 0.74 & & \\
\hline $16-2,104$ & 74.55 & 1.27 & -0.02 & 2.48 & 1.14 & & \\
\hline $16-3,103$ & 76.03 & 1.11 & -0.07 & 2.47 & 0.92 & & \\
\hline $17-3,100$ & 78.00 & 1.18 & 0.01 & 2.30 & 1.24 & & \\
\hline $18-3,103$ & 86.03 & 1.21 & -0.20 & 2.42 & 0.88 & & \\
\hline $19-3,146$ & 91.46 & 1.42 & 0.46 & 2.43 & 1.25 & & \\
\hline $20-3,005$ & 95.05 & 1.51 & 0.28 & 2.33 & 1.14 & & \\
\hline $21-2,105$ & 97.55 & 1.40 & 0.19 & 2.54 & 1.19 & 2.44 & 0.61 \\
\hline $22-2,097$ & 101.47 & 1.71 & 0.24 & 2.48 & 1.19 & 2.69 & 1.11 \\
\hline $23-1,103$ & 105.03 & 1.82 & 0.10 & 2.54 & 0.84 & & \\
\hline $23-2,102$ & 106.52 & 1.90 & 0.27 & 2.82 & 1.24 & 2.69 & 1.11 \\
\hline $23-3,106$ & 108.06 & 1.59 & -0.03 & 2.51 & 0.62 & & \\
\hline $24-1,102$ & 109.52 & 1.25 & 0.22 & 2.61 & 0.98 & & \\
\hline $24-2,102$ & 111.02 & 1.27 & 0.19 & 2.31 & 0.97 & & \\
\hline $24-3,106$ & 112.56 & 1.44 & 0.03 & 2.45 & 0.93 & & \\
\hline $25-1,144$ & 114.94 & 1.43 & 0.21 & 2.48 & 0.76 & & \\
\hline $25-2,144$ & 116.44 & 1.36 & 0.12 & 2.38 & 1.09 & & \\
\hline $25-3,144$ & 117.94 & 1.24 & 0.19 & 2.29 & 1.09 & & \\
\hline $26-1,032$ & 118.82 & 1.71 & -0.01 & 2.91 & 0.88 & & \\
\hline $26-2,032$ & 120.32 & 1.67 & -0.36 & 2.59 & 0.75 & & \\
\hline $26-3,032$ & 121.82 & 1.27 & -0.16 & 2.57 & 0.83 & & \\
\hline $27-1,034$ & 123.84 & 1.57 & 0.00 & 2.38 & 0.86 & & \\
\hline $27-2,034$ & 125.34 & 1.62 & -0.10 & 2.56 & 0.97 & & \\
\hline $27-3,034$ & 126.84 & 1.40 & -0.06 & 2.50 & 0.80 & & \\
\hline $28-2,022$ & 130.22 & 1.29 & 0.46 & 2.31 & 0.75 & & \\
\hline $28-3,022$ & 131.72 & 1.37 & 0.35 & 2.38 & 1.07 & & \\
\hline $28-4,022$ & 133.22 & 1.66 & 0.11 & 2.26 & 1.09 & & \\
\hline $29-1,046$ & 133.96 & 1.28 & 0.09 & 2.37 & 0.77 & & \\
\hline $29-2,046$ & 135.46 & 1.44 & 0.28 & 2.38 & 0.99 & & \\
\hline $29-3,046$ & 136.96 & 1.51 & -0.04 & 2.31 & 0.88 & & \\
\hline $31-3,090$ & 147.40 & 1.41 & 0.64 & 2.20 & 1.16 & & \\
\hline $32-2,110$ & 151.10 & & & 2.14 & 1.34 & & \\
\hline $33-1,080$ & 154.30 & 1.43 & 0.74 & 2.32 & 1.20 & & \\
\hline $34-2,130$ & 161.30 & 1.22 & 0.45 & 2.34 & 1.16 & & \\
\hline
\end{tabular}

middle/upper Miocene and Miocene/Pliocene boundary (taken from results produced onboard ship) would argue that change between 120 and $130 \mathrm{~m}$ is time-equivalent with that at other locations. In contrast to Caribbean Site 502 (Keigwin, 1982) and western North Atlantic 410,the Cibicidoides do not show a negative shift in the uppermost Miocene. This may result from different watermass histories for Sites 502 and 410, which underlie water of western North Atlantic origin unlike eastern North Atlantic Hole 552A. Alternatively, the preliminary stratigraphy used in Figure 1 might be in error, and the $\delta^{13} \mathrm{C}$ shift dated at $\sim 6 \mathrm{~m}$.y. could be at $\sim 140 \mathrm{~m}$.

\section{SUMMARY}

Generally, small and frequent changes in upper Miocene and lower Pliocene foraminiferal $\delta^{18} \mathrm{O}$ and $\delta^{13} \mathrm{C}$ in Hole $552 \mathrm{~A}$ are not easily interpreted without correlation with other sites. At present the best guess is that sediment time-equivalent with the late Miocene $\delta^{13} \mathrm{C}$ shift occurs between $\sim 120$ and $130 \mathrm{~m}$ down core. Cores 25 through 28 have been sampled every $10 \mathrm{~cm}$ for further study. It is hoped that this interval will be correlated with results from North Atlantic DSDP Site 610E, where magnetic epochs 5 and 6 have been recognized. Results

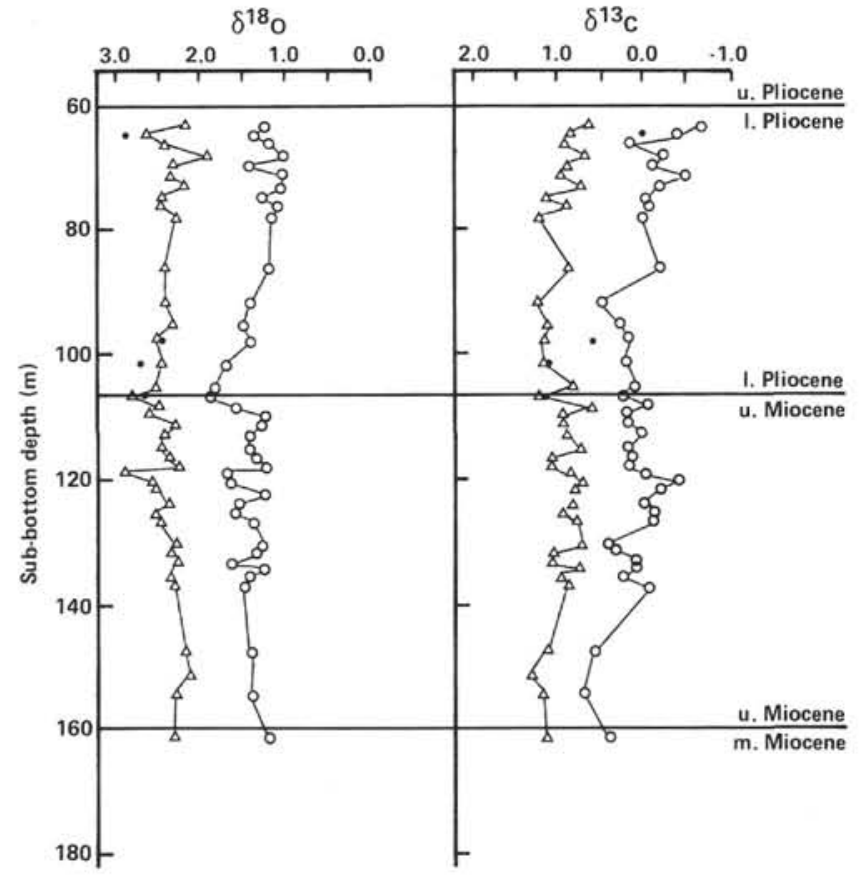

Figure 1. Oxygen and carbon isotopic results on $G$. bulloides (open circles), C. wuellerstorfi (triangles), and C. kullenbergi (solid points), DSDP Hole 552A.

of this comparison will appear in the Initial Reports of Leg 94 .

\section{ACKNOWLEDGMENTS}

This work was supported by NSF Grant 8117590 (Submarine Geology and Geophysics). The author is indebted to C. E. Franks, R. Gorski, A. Tricca, and A. Witter for technical assistance. Helpful comments on the manuscript were provided by D. A. Johnson and W. B. Curry. This is Woods Hole Oceanographic Institution Contribution No. 5602 .

\section{REFERENCES}

Bender, M. L., and Keigwin, L. D., Jr., 1979. Speculations about the upper Miocene change in abyssal Pacific dissolved bicarbonate $\delta^{13}$ C. Earth Planet. Sci. Lett., 45:383-393.

Blanc, P. L., Rabussier, D., Vergnaud Grazzini, C., and Duplessy, J. C., 1980. North Atlantic Deep Water formed by the later middle Miocene. Nature, 283 (5747):553-555.

Brunner, C. A., and Keigwin, L. D. Jr., 1981. Late Neogene biostratigraphy and stable isotope stratigraphy of a drilled core from the Gulf of Mexico. Mar. Micropaleontol., 6:397-418.

Keigwin, L. D., Jr., 1979. Late Cenozoic stable isotope stratigraphy and paleoceanography of DSDP sites from the east equatorial and central North Pacific Ocean. Earth Planet Sci. Lett., 45:361-382. 1982. Isotopic paleoceanography of the Caribbean and East Pacific: Role of Panama uplift in Late Neogene time. Science, 217:350-353.

Keigwin, L. D., Jr., and Shackleton, N. J., 1980. Uppermost Miocene carbon isotope stratigraphy of a piston core in the equatorial $\mathrm{Pa}$ cific. Nature, 284:613-614.

Keigwin, L. D., Jr., and Thunell, R. C., 1979. Middle Pliocene climatic change in the western Mediterranean from faunal and oxygen isotopic trends. Nature, 282:294-296.

Kennett, J. P., Shackleton, N. J., Margolis, S. V., Goodney, D. E., Dudley, W. C., and Kroopnick, P. M., 1979. Late Cenozoic oxygen and carbon isotopic history and volcanic ash stratigraphy: DSDP Site 284, South Pacific. Am. J. Sci., 279: 52-69.

Loutit, T. S., and Kennett, J. P., 1979. Application of carbon isotope stratigraphy to late Miocene shallow marine sediments, New Zealand. Science, 204:1196-1199. 
Shackleton, N. J., and Cita, M. B., 1979. Oxygen and carbon isotope stratigraphy of benthic foraminifers at Site 397: Detailed history of climatic change during the late Neogene. In von Rad, U., Ryan , W. B. F. et al., Init. Reports DSDP, 47: Washington, (U.S. Govt. Printing Office), 442-445.

Shackleton, N. J., and Kennett, J. P., 1975. Paleotemperature history of the Cenozoic and the initiation of Antarctic glaciation: Oxygen and carbon isotope analyses in DSDP Sites $277,279,281$. In Kennett, J. P., Houtz, R. E., et al., Init. Repts. DSDP. 29: Washington, (U.S. Govt. Printing Office), 743-756.
Vincent, E., Killingley, J. S., and Berger, W. H., 1980. The magnetic Epoch-6 carbon shift: A change in the oceans ${ }^{13} \mathrm{C} /{ }^{12} \mathrm{C}$ ratio 6.2 million years ago. Mar. Micropaleontol., 5:185-203.

Woodruff, F., Savin, S. M., and Douglas, R. G., 1981. Miocene stable isotope record: A detailed deep Pacific Ocean study and its paleoclimatic implications. Science, 212:665-668.

Date of Acceptance: February 6, 1984 